\title{
IDENTIFIKASI DAN KEANEKARAGAMAN JENIS IKAN YANG TERTANGKAP DI SUNGAI BATANG BUNGO KABUPATEN BUNGO PROVINSI JAMBI
}

\author{
Oktawan Syaputra, Rini Hertati, Budiyono
}

\begin{abstract}
ABSTRAK
Perikanan adalah salah satu usaha untuk memanfaatkan sumber daya hayati perairan salah satu wujud nyata dari pemanfaatan sumber daya perikanan yang cukup besar dilakukan baik di perairan laut maupun perairan umum. Penelitian ini dilaksanakan pada tanggal tanggal 1 Januari sampai dengan 5 Februari 2017, bertempat di Sungai Batang Bungo, Kelurahan Sungai Pinang Kecamatan Bungo Dani, Dusun Tebat Kecamatan MukoMuko Bathin VII dan Muaro Buat Kecamatan Bathin III Ulu Kabupaten Bungo Propinsi Jambi dengan kedalaman 1-6 meter dan luas $5000 \mathrm{~m}^{2}$.

Tujuan dari penelitian ini adalah untuk mengetahui jenis ikan yang sengaja ditangkap dan Untuk mengetahui Indeks Keanekaragaman jenis ikan, Kepadatan Populasi, Kepadatan Relatif dan Frekuensi Kehadiran pada 3 stasiun yang telah ditentukan yaitu di Kelurahan Sungai Pinang Kec. Bungo Dani, Dusun Tebat Kec. Muko-Muko Bathin VII dan Dusun Muaro Buat Kec. Bathin III Ulu Kabupaten Bungo Propinsi Jambi.

Metode yang yang digunakan dalam penelitian ini adalah Metode Purposive Sampling yaitu penentuan stasiun penelitian dilakukan berdasarkan tujuan dengan memperhatikan berbagai pertimbangan kondisi dan keadaan tempat penelitian atau karakteristik seperti kondisi dominan aktivitas penambangan pasir dan lain-lain. Populasi dalam penelitian ini adalah semua jenis ikan yang tertangkap di Sungai Batang Bungo. Sedangkan sampel dalam penelitian ini adalah perwakilan setiap jenis ikan yang tertangkap pada masing-masing stasiun yang telah ditentukan dengan luas areal lebih kurang $5.000 \mathrm{~m}^{2}$.

Hasil penelitian menunjukkan bahwa jenis ikan yang tertangkap selama penelitian dari Tiga Stasiun di Sungai Batang Bungo ditemukan sebanyak 156 ekor, terdiri dari 16 jenis yang mewakili 5 Ordo, 9 Famili dan 15 Genus dan hasil analisis indeks keanekaragaman jenis menunjukkan indeks keanekaragaman berkisar antara 0,58 hingga 1,46 Indeks keanekaragaman tertinggi di jumpai di Stasiun I Dusun Buat, Stasiun III Kelurahan Sungai Pinang, dan terendah terdapat pada Stasiun II di Dusun Tebat. Kepadatan Populasi (KP) tertinggi dari tiga stasiun yaitu, Tilan (Microphis brachyurus) sebesar 0.0042 (individu) / $\mathrm{m}^{2}$, Kepadatan Relatif (KR) tertinggi terapat pada Tilan (Mastcembetus unicdar), Seluang (Rasbora argyrotaenia), sedangkan untuk Frekuensi Kehadiran (FK) tertinggi yaitu Tilan (Microphis brachyurus), Lampam (Puntius schwanepeldi), Lais (Criptopterus limpok (Blkr)), Gurami (Osphronemus gouramy), Baung (Mystus nemurus) masing-masing $100 \%$.
\end{abstract}

Kata Kunci : Identifikasi, Keanekaragaman, Kepadatan Populasi, Jenis Ikan 
SEMAH : Journal Pengelolaan Sumberdaya Perairan

VOL. 1 No. 2

Desember 2017

\section{Pendahuluan}

Perairan Sungai Batang Bungo merupakan salah satu sungai utama di KabupatenBungo dan merupakan bentuk perairan yang terbuka dan panjang mencapai kurang lebih50 km. Hasil observasi di lapangan bahwa bagi masyarakat petani nelayan sungai inidimanfaatkan untuk usaha penangkapan ikan dan budidaya perikanan. Disamping itu bagi masyarakat umum disepanjang pinggiran Sungai Batang Bungo dimanfaatkan untuk mencuci, mandi dan jamban (MCK) serta kebutuhan rumah tangga lainnya. Sedangkanuntuk masyarakat yang jaraknya jauh dari perairan Sungai Batang Bungo juga digunakanuntuk penyedia air minum yang dikelola oleh PDAM dan dialirkan kerumah-rumah penduduk dan jasa transportasi

Sungai Batang Bungo merupakan suatu perairan yang banyak dimanfaatkan oleh beberapa sektor seperti pertanian, perikanan, pertambangan, perhubungan dan juga merupakan sumber air minum masyarakat di Bungo. Adanya berbagai aktivitas manusia di sekitar perairan sungai Batang Bungo akan memberikan dampak yang negatif terhadap ekosistem perairan Sungai Batang Bungo, sehingga Sungai Batang Bungo akan mengalami perubahan-perubahan ekologis dimana kondisinya sudah berbeda dengan kondisi alami yang semula.

Diantara komponen biotik, ikan merupakan salah satu organisme akuatik yang rentan terhadap perubahan lingkungan terutama yang di akibatkan oleh aktivitas manusia baik secara langsung maupun tidak langsung. Limbah-limbah bahan buangan yang di hasilkan oleh berbagai aktivitas manusia tersebut mempengaruhi kualitas
ojs.umb-bungo.ac.id/index-php/SEMAHJPSP

perairan baik fisik, kimia dan biologis diantaranya penyebaran ikan (Rifa'i, $d k k, 1983)$.

Dengan adanya perubahan ekologis pada perairan Sungai Batang Bungo maka di perkirakan memberi pengaruh terhadap keanekaragaman mahluk hidup di dalamnya. Keanekaragaman yang tinggi di suatu perairan menunjukan keadaan komunitas yang baik, sebaliknya keanekaragaman yang kecil berarti telah terjadi ketidak seimbangan ekologis di perairan tersebut (Koesbiono, 1989).

Keanekaragaman jenis ikan hasil penelitian di empat stasiun Sungai Batang Bungo ditemukan sebanyak 25 jenis ikan dari 16 genus dan 9 famili (Budiyono, 2011). Selanjutnya Sudrajat, $d k k, 2009$ mengemukakan bahwa hasil studi di Propinsi Jambi menunjukkan jenis ikan tawar yang ada berjumlah 131 species yang tercakup ke dalam 14 ordo dan 25 famili. Sedangkan informasi tentang ekologi perairan umum di Jambi masih sangat terbatas. Secara umum Penelitian yang terpublikasi masih dianggap sangat kurang mengingat datadata dasar yang bersifat time series atau tahunan masih belum dilakukan secara intensif (Sudrajat, et al, 2009 dalam Budiyono 2011).

\section{Metode Penelitian}

Penelitian ini dilaksanakan pada tanggal 1 Januari 2017 sampai dengan 5 Februari 2017. Penelitian ini dilakukan di Sungai Batang Bungo, Kelurahan Sungai Pinang Kecamatan Bungo Dani, Dusun Tebat Kecamatan Muko-Muko Bathin VII dan Muaro Buat Kecamatan Bathin III Ulu Kabupaten Bungo Propinsi Jambi dengan kedalaman 1-6 meter dan lebar 30 - 50 meter. 
SEMAH : Journal Pengelolaan Sumberdaya Perairan

VOL. 1 No. 2

Desember 2017

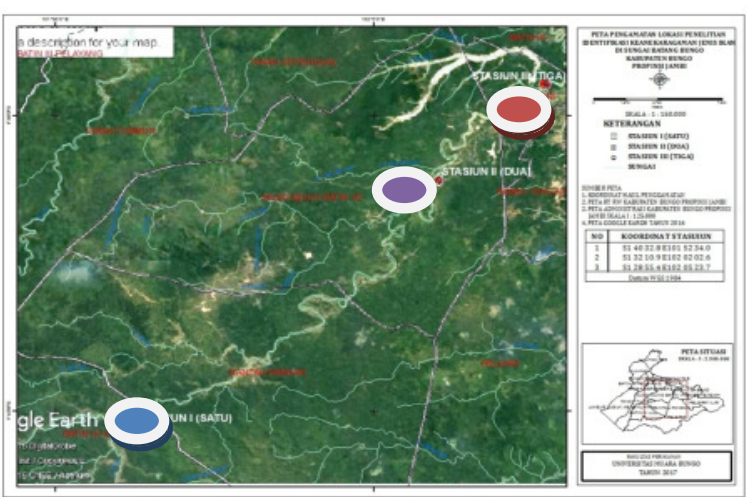

Gambar 3.1 Peta Lokasi penelitian

Berdasarkan tujuan penelitian yang akan dicapai dan metode penelitian yang akan digunakan yaitu untuk data primer dengan cara observasi langsung dilapangan dan melakukan wawancara kepada nelayan setempat sebagai sumber informasi langsung yang ada
ojs.umb-bungo.ac.id/index-php/SEMAHJPSP

dilapangan, serta data sekunder diperoleh dari Dinas dan Instansi terkait dan hasil tangkapan nelayan sekitar Sungai Batang Bungo serta referensi atau hasil penelitian maupun jurnal penelitian.

Dalam penentuan stasiun penelitian ini digunakan Metode Purposive Sampling yaitu penentuan stasiun penelitian dilakukan berdasarkan tujuan dengan memperhatikan berbagai pertimbangan kondisi dan keadaan tempat penelitian atau karakteristik seperti kondisi dominan aktivitas penambangan pasir dan lain-lain.

Populasi dalam penelitian ini adalah semua jenis ikan yang tertangkap di Sungai Batang Bungo. Sedangkan sampel dalam penelitian ini adalah perwakilan setiap jenis ikan yang

Tabel 4.1 Keanekaragaman Jenis Ikan di Sungai Batang Bungo Kabupaten Bungo.

\begin{tabular}{|c|c|c|c|c|c|c|}
\hline \multirow[t]{2}{*}{ No } & \multirow[t]{2}{*}{ Genus/spesies } & \multirow[t]{2}{*}{ Nama Daerah } & \multicolumn{3}{|c|}{ Stasiun } & \multirow[t]{2}{*}{ Total (n) } \\
\hline & & & $I$ & II & III & \\
\hline \multirow[t]{4}{*}{1} & Bagridae & & & & & \\
\hline & Mystus nemurus & Baung & 4 & 4 & 3 & 11 \\
\hline & Macrones nigriceps(C.V) & Singgiring & 3 & 1 & 1 & 5 \\
\hline & $\begin{array}{c}\text { Leiocassic micropogon } \\
\text { Pangasidae }\end{array}$ & Kepuntin & 2 & - & - & 2 \\
\hline 2 & $\begin{array}{c}\text { Criptopterus limpok(Blkr) } \\
\text { Cyprinidae }\end{array}$ & Lais & 6 & 3 & 5 & 14 \\
\hline \multirow{4}{*}{3} & Thinnicthys thynnoides & Lambak & 2 & 1 & 15 & 18 \\
\hline & Rasbora argyrotaenia & Seluang & 7 & - & 3 & 10 \\
\hline & Osteochilus hasseti(C.V) & Palau & 2 & 2 & 3 & 7 \\
\hline & $\begin{array}{l}\text { Puntius schwanefeldi } \\
\text { Mastacenbeidae }\end{array}$ & Lampam & $\overline{7}$ & 2 & 6 & 15 \\
\hline 4 & $\begin{array}{l}\text { Microphisbrachyurus } \\
\text { Ngndidae }\end{array}$ & Tilan & 17 & 2 & 2 & 21 \\
\hline 5 & $\begin{array}{l}\text { pristolepis grooti } \\
\text { Ophiochephalidae }\end{array}$ & Batung & 3 & 4 & 2 & 9 \\
\hline 6 & $\begin{array}{c}\text { Ophiocephalus striatus BI } \\
\text { Anabantidae }\end{array}$ & Gabus & 2 & 2 & 3 & 7 \\
\hline \multirow{2}{*}{7} & Osphronemus goramy lac & Gurami & 6 & 4 & 2 & 12 \\
\hline & Anabas tertudineus B.L) & Betok & - & - & 5 & 5 \\
\hline \multirow[t]{2}{*}{8} & $\begin{array}{l}\text { Helostoma temmincki } \\
\text { Cichlidae }\end{array}$ & Tambakang & - & - & 5 & 5 \\
\hline & $\begin{array}{c}\text { Oreochormis niloticus } \\
\text { Eleotridae }\end{array}$ & Nila & 1 & - & 6 & 7 \\
\hline \multirow{4}{*}{9} & Oxyeleotris marmorata & Betutu & 4 & 1 & 3 & 8 \\
\hline & Total Individu & & 66 & 26 & 64 & 156 \\
\hline & Total Spesies & & 14 & 11 & 15 & 39 \\
\hline & Total Genus & & 9 & 8 & 9 & 9 \\
\hline
\end{tabular}

Sumber : Olahan Data Penelitian Januari 2017 
SEMAH : Journal Pengelolaan Sumberdaya Perairan

VOL. 1 No. 2

Desember 2017

tertangkap di hulu, pertengahan dan muara, atau tiap-tiap Stasiun di Sungai Batang Bungo, Kabupaten Bungo Propinsi Jambi pada bulan Januari 2017. Dalam melakukan penangkapan ini penulis melakukan 3 hari untuk 1 stasiun dengan 3 kali ulangan setiap harinya dengan luas areal penangkapan masing-masing stasiun seluas $5.000 \mathrm{~m}^{2}$. Untuk menganalisis data yang diperoleh dari lapangan digunakan beberapa metoda analisis Indeks Keanekaragaman Jenis Ikan (Hi) dan Kepadatan Populasi, Kepadatan Relatif dan Frekuensi Kehadiran.

\section{Hasil dan Pembahasan}

1. Keanekaragaman Jenis Ikan di Sungai Batang Bungo (Hi)

Selama penelitian dilakukan, ikan yang berhasil dikumpulkan berjumlah 156 ekor, terdiri dari 16 jenis yang mewakili 5 Ordo, 9 Famili dan 15 Genus, (Tabel 4.1).

Hasil pengamatan menunjukkan adanya keragaman jenis ikan yang diperoleh di Sungai Batang Bungo. Stasiun I (Dusun Buat) tercatat ada 14 jenis dan 9 genus dari jumlah total individu yang ditemukan sebanyak 66 ekor. Stasiun II (Dusun Tebat) ditemukan 11 jenis dan 8 genus dari total individu yang ditemukan sebanyak 26 ekor, distasiun III (Kelurahan Sungai Pinang) ditemukan 15 jenis dan 9 genus dari 64 ekor ikan.

Jenis ikan terbanyak di perairan Sungai Batang Bungo terdiri dari famili Cyprinidae (4 jenis), Anabantidae (3 jenis) dan Bagridae (3 jenis). Menurut Kottelat et al (1993) bahwa jenis ikan Cyprinidae merupakan penghuni utama yang paling besar jumlah populasinya untuk beberapa Sungai di Propinsi Jambi selain jenis Bagridae.

Total jumlah ikan yang didapat Sungai Batang Bungo paling banyak
ojs.umb-bungo.ac.id/index-php/SEMAHJPSP

ditemukan adalah jenis Microphis brachyurus sebanyak 21 ekor, diikuti oleh Thinnicthys thynnoides sebanyak 18 ekor, Puntius schwanefeldi sebanyak 15 ekor, Criptopterus limpok (Blkr) sebanyak 14 ekor, Osphronemus goramy lac sebanyak 12 ekor, Mystus nemurus sebanyak 11 ekor dan Rasbora argyrotaenia .Blkr sebanyak 10 ekor. Sedangkan jumlah total ikan paling sedikit adalah jenis ikan Leiocassic micropogon hanya 2 ekor dan Oreochormis niloticus sebanyak 1 ekor. Jumlah total ikan berhubungan dengan kehadiran jenis ikan disetiap stasiun pengamatan. Kehadiran jenis berpengaruh terhadap jumlah jenis, individu, famili dan mempengaruhi pula dengan nilai keanekaragaman, kemerataan serta dominansi pada setiap stasiun (Magurran 1988).

Kehadiran ikan tidak terlepas dengan peletakan alat tangkap yang digunakan di setiap stasiun. Kondisi stasiun pengamatan yang berbeda membuat jenis alat tengkap tertentu tidak digunakan. Misalnya pada stasiun I (Dusun Muaro Buat) tidak dipasang Jaring (gill net) karena tepian dan dasar sungai berbatu sehingga mempengaruhi dalam pemasangan gill net dan alat tembak tidak digunakan pada Stasiun II dan stasiun III di karenakan airnya cukup keruh sehingga tidak memungkinkan untuk melakukan penangkapan dengan alat tangkap tembak. Tujuan penggunaan setiap alat tangkap dapat mempengaruhi jumlah komposisi jenis dan individu, dikarenakan setiap alat tangkap memiliki kelebihan dan kelemahan masing-masing. Jumlah alat tangkap dan lama waktu mempengaruhi banyaknya tangkapan, semakin banyak jenis alat tangkap, jumlah alat tangkap dan lama waktu pengambilan sampel maka akan mengakibatkan jumlah 
SEMAH : Journal Pengelolaan Sumberdaya Perairan

VOL. 1 No. 2

Desember 2017

individu dan variasi jenis ikan melimpah (Novri 2006).

Untuk melihat jumlah ikan yang tertangkap pada masing-masing alat tangkap dapat disajikan pada tabel 4.2
ojs.umb-bungo.ac.id/index-php/SEMAHJPSP

ISSN : 2580-0736

Tabel 4.2. Jumlah Ikan yang Tertangkap Pada Masing-Masing Alat Tangkap diSungai Batang Bungo

\begin{tabular}{|c|c|c|c|c|c|c|c|c|c|c|c|}
\hline \multirow{2}{*}{ Nama Jenis } & \multicolumn{4}{|c|}{ Stasiun I } & \multicolumn{3}{|c|}{ Stasiun II } & \multicolumn{3}{|c|}{ Stasiun III } & \multirow{2}{*}{ Jumlah } \\
\hline & 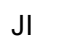 & $J \mathrm{~L}$ & $P G$ & TK & $\mathrm{Jl}$ & $\mathrm{JL}$ & $P G$ & 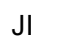 & $\mathrm{JL}$ & $P G$ & \\
\hline Mystus nemurus & - & 1 & 1 & 2 & - & 3 & 1 & - & 1 & 2 & 11 \\
\hline Macrones nigriceps(C.V) & 1 & 2 & - & - & - & 1 & - & - & 1 & - & 5 \\
\hline Leiocassic micropogon & - & 1 & - & 1 & - & - & - & - & - & - & 2 \\
\hline Criptopterus limpok & 2 & 3 & 1 & - & 1 & 1 & 1 & 2 & 2 & 1 & 14 \\
\hline Thinnicthys thynnoides & - & 2 & - & - & - & 1 & - & 4 & 7 & 3 & 17 \\
\hline Rasbora argyrotaenia & 2 & 4 & 1 & - & - & - & - & 1 & 2 & - & 10 \\
\hline Osteochilus hasseti(C.V) & - & 1 & - & 1 & 1 & 1 & - & 1 & 2 & - & 7 \\
\hline Puntius schwanefeldi & 2 & 3 & 1 & 1 & 1 & 1 & - & 1 & 3 & 2 & 15 \\
\hline MicrophisBrachyurus & 1 & 5 & 2 & 9 & - & 1 & 1 & - & - & 2 & 21 \\
\hline pristolepis grooti & 1 & 1 & 1 & - & 1 & 2 & 1 & 1 & 1 & - & 9 \\
\hline Ophiocephalus striatus BI & - & - & 1 & 1 & - & - & 2 & 1 & - & 2 & 7 \\
\hline Osphronemus goramy lac & 3 & 1 & - & 2 & 2 & 1 & 1 & 1 & 1 & - & 12 \\
\hline Anabas tertudineus B.L) & - & - & - & - & - & - & - & 1 & 2 & 2 & 5 \\
\hline Helostoma temmincki & - & - & - & - & - & - & - & 3 & 2 & - & 5 \\
\hline Oreochormis niloticus & - & - & 1 & - & - & - & - & 2 & 1 & 3 & 7 \\
\hline Oxyeleotris marmorata & - & 1 & 1 & 2 & - & - & 1 & - & 1 & 2 & 8 \\
\hline Jumlah & 12 & 26 & 10 & 20 & 6 & 12 & 8 & 18 & 26 & 19 & 156 \\
\hline
\end{tabular}

Sumber : Olahan Data Penelitian Januari 2017

Keterangan :

$$
\begin{array}{ll}
\mathrm{JI} & =\text { Jaring Insang } \\
\mathrm{JL} & =\text { Jala Lempar } \\
\mathrm{PG} & =\text { Pancing } \\
\mathrm{TK} & =\text { Tembak }
\end{array}
$$

Dari data Tabel di atas dapat dijelaskan bahwa jumlah ikan yang tertangkap pada setiap Stasiun dengan alat tangkap Jala lempar merupakan hasil tangkapan terbanyak dengan jumlah 63 ekor, diantaranya pada Stasiun I sebanyak 25 ekor, pada Stasiun II sebanyak 12 ekor dan Pada Stasiun III sebanyak 26 ekor. Sedangkan jumlah ikan yang paling sedikit terdapat pada alat tangkap pada masing-masing stasiun yaitu Jala insang dengan jumlah tangkapan sebanyak 36 ekor, diantaranya pada Stasiun I sebanyak 12 ekor, Stasiun II sebanyak 6 ekor dan pada Stasiun II sebanyak 18 ekor.

Hasil analisis indeks keanekaragaman jenis menunjukkan indeks keanekaragaman berkisar antara 0,58 hingga 1,46 Indeks keanekaragaman tertinggi di jumpai di Stasiun III Kelurahan Sungai Pinang serta terendah terdapat pada Stasiun II di Dusun Tebat. 
SEMAH : Journal Pengelolaan Sumberdaya Perairan

VOL. 1 No. 2

Desember 2017

lebih besar dibandingkan dengan area yang lebih sempit, sehingga semakin panjang dan lebar ukuran sungai semakin banyak pula jumlah ikan yang menempatinya (Kottelat et al 1993). Adanya hubungan positif antara kekayaan jenis dengan suatu area yang ditempati berhubungan pula dengan keanekaragaman jenis ikan. Stasiun III juga merupakan daerah yang dekat dengan Aliran Sungai Batang Tebo, mengalami perombakan air sehingga memperbaiki kualitas air melalui fenomena pertemuan 2 aliran air sungai. Meskipun stasiun ini memiliki warna air yang keruh dan subtrat dasarnya berlumpur bepasir.
ojs.umb-bungo.ac.id/index-php/SEMAHJPSP

Tabel 4.3 Jumlah Jenis, Individu, Famili, Indeks Keanekaragam Jenis Ikan di Sungai Batang Bungo.

\begin{tabular}{lcccc}
\hline \multirow{2}{*}{ Keterangan } & \multicolumn{3}{c}{ Jumlah } & \multirow{2}{*}{ Total } \\
\cline { 2 - 4 } & ST I & ST II & ST III & \\
\hline Jumlah Jenis & 14 & 11 & 15 & $\mathbf{1 6}$ \\
Jumlah Famili & 9 & 8 & 9 & $\mathbf{9}$ \\
Jumlah Induvidu & 66 & 26 & 64 & $\mathbf{1 5 6}$ \\
Indeks Keanekaragaman Jenis & $\mathbf{1 , 3 6}$ & $\mathbf{0 , 5 8}$ & $\mathbf{1 , 4 6}$ & \\
\hline Sumber : Olahan Data Penelitian Januari 2017 & & &
\end{tabular}

Ikan memiliki kemelimpahan yang beragam pada waktu dan lokasi yang berbeda. Jenis ikan yang memiliki kelimpahan tertinggi dan juga dominansi pada pengamatan di tiga Stasiun di Sungai Batang Bungo adalah Microphis brachyurus sebanyak 21 ekor, diikuti oleh Thinnicthys thynnoides sebanyak 18 ekor, Puntius schwanefeldi sebanyak 15 ekor, Criptopterus limpok (Blkr) sebanyak 14 ekor, Osphronemus goramy lac sebanyak 12 ekor, Mystus nemurus sebanyak 11 ekor dan Rasbora argyrotaenia sebanyak 10 ekor. Jenisjenis tersebut memiliki kelimpahan tertinggi karena memiliki kemampuan dalam beradaptasi dan dapat memanfaatkan potensi sumberdaya yang ada untuk mencukupi hidup (Mann, 1981 dalam., Gonawi, 2009).

Jumlah individu yang besar dan berkelompok juga menjadi mempengaruhi kemelimpahan tinggi karena dapat dijumpai dalam jumlah besar pada tiap pengamatan. Selain faktor di atas, kemampuan dalam mencari makan juga mempengaruhi kemelimpahan jenis ikan. Jenis ikan (Mastacenbelidae) memiliki semacam mulut yang berfungsi dalam mendeteksi sumber makanan. Jenis ikan ini, umumnya memiliki tipe mulut superior yang memungkinkan ikan mendapatkan makanan di dasar sungai (Heok, 2009).

Bentuk mulut ikan juga mempengaruhi preferansi habitat atau pembagian relung ekologi dan perbedaan dalam cara atau teknik mendapatkan makanannya. Jenis ikan
Cyprinidae cenderung ditepi sungai untuk mendapatkan makanan. Tipe mulut terminal dan subterminal memungkinan jenis Cyprinidae memakan lumut atau alga yang tumbuh dibawah pepohonan bebatuan tepi sungai. Kebiasaan makanan ikan dipengaruhi oleh berbagai faktor penting yaitu kondisi habitat, kesukaan terhadap jenis makanan tertentu, ukuran dan umur ikan. Perubahan kondisi lingkungan juga mempengaruhi perubahan persedaiaan makanan dan akan merubah perilaku makan ikan (Zahid, 2008).

Keberadaan ikan di suatu tempat tidak terlepas dari kondisi habitat sebagai penyedia sumberdaya bagi kebutuhan hidup ikan. Adanya variasi kondisi habitat menyebabkan ikan harus berinteraksi termasuk beradaptasi dengan habitatnya. Bentuk adaptasi ikan terhadap habitat antara lain adaptasi 
SEMAH : Journal Pengelolaan Sumberdaya Perairan

VOL. 1 No. 2

Desember 2017

morfologi pada tipe letak mulut, tipe gigi rahang bawah dan bentuk sirip ekor. Tipe letak mulut, tipe gigi rahang bawah dan bentuk sirip ekor menunjukan adaptasi ikan terkait dengan sumberdaya makanan dan cara memperolehnya (guild). Pengelompokan ikan berdasarkan cara memperoleh makanan (guild) telah dikenal yaitu herbivora endogenus (pemakan lumut dan alga), herbivora eksogenus (pemakan buah,daun dan biji yang jatuh ke sungai), karnivora pemakan binatang kecil (pemakan plakton, nematoda dan rotifera), karnivora pemakan serangga, karnivora pemakan ikan lain dan omnivora (Kottelat et al., 1993).

2. Kepadatan Populasi, Kepadatan Relatif dan Frekuensi Kehadiran.

Berdasarkan hasil sampel ikan yang tertangkap pada saat penelitian dapat disajikan pada hasil perhitungan
ojs.umb-bungo.ac.id/index-php/SEMAHJPSP
Kepadatan Populasi, Kepadatan Relatif, dan Frekuensi Kehadiran pada Tabel 4.4 .

Dari Tabel dapat dijelaskan bahwa kepadatan Populasi (KP) tertinggi ditemukan pada jenis Ikan : Tilan (Microphis brachyurus) sebesar $0.0042 \quad$ (individu) $/ \mathrm{m}^{2}$, Lambak, Thinnicthys thynnoides, 0.0036 (individu $/ \mathrm{m}^{2}$ ) , Lampam (Puntius schwanefeldi) sebesar 0.003 (individu / $\mathrm{m}^{2}$ ), Baung (Mystus nemurus) sebesar 0,0022 (individu $/ \mathrm{m}^{2}$ ), Lais (Criptopterus limpok (Blkr) sebesar 0.0028 (individu / $\mathrm{m}^{2}$ ). Hal ini di duga karena kualitas air yang baik serta jenis-jenis ikan ini memiliki kemampuan dalam mencari makanan. Hal ini sesuai dengan pendapat Mann, (1981) dalam Gonawi, (2009) Jenis-jenis tersebut memiliki kelimpahan tertinggi karena memiliki kemampuan dalam beradaptasi dan dapat memanfaatkan potensi sumberdaya yang ada untuk mencukupi hidup.

Tabel 4.4. Hasil Perhitungan Kepadatan Populasi, Kepadatan Relatif, dan Frekuensi Kehadiran.

\begin{tabular}{clccc}
\hline No & \multicolumn{1}{c}{ Jenis Ikan } & KP & KR & FK \\
\hline 1 & Mystus nemurus & 0,0022 & 7.0512 & 100.00 \\
2 & Macrones nigriceps (C.V) & 0.001 & 3.2051 & 66.66 \\
3 & Leiocassic micropogon & 0,0004 & 1.2820 & 33.33 \\
4 & Criptopterus limpok(Blkr) & 0.0028 & 8.9743 & 100.00 \\
5 & Thinnicthys thynnoides & 0.0036 & 11.538 & 100.00 \\
6 & Rasbora argyrotaenia & 0.002 & 6.4102 & 66.66 \\
7 & Osteochilus hasseti(C.V) & 0.0014 & 4.4871 & 66.66 \\
8 & Puntius schwanefeldi & 0.003 & 9.6153 & 100.00 \\
9 & Microphis brachyurus & 0.0042 & 13.461 & 100.00 \\
10 & pristolepis grooti & 0.018 & 5.7692 & 66.66 \\
11 & Ophiocephalus striatus BI & 0.0014 & 4.4871 & 66.66 \\
12 & Osphronemus goramy lac & 0.0024 & 7.6923 & 66.66 \\
13 & Anabas tertudineus B.L & 0.001 & 3.2051 & 33.33 \\
14 & Helostoma temmincki & 0.001 & 3.2051 & 33.33 \\
15 & Oreochormis niloticus & 0.0014 & 4.4871 & 66.66 \\
16 & Oxyeleotris marmorata & 0.0016 & 5,1282 & 66.66 \\
& & & & $\mathbf{6 4 , 2 0 \%}$ \\
\hline & Total & $\mathbf{0 . 6 2 7 5}$ & & \\
\hline Sumb & Olanan Data Penelian Jan & & \\
\hline
\end{tabular}

Sumber : Olahan Data Penelitian Januari 2017 
SEMAH : Journal Pengelolaan Sumberdaya Perairan

VOL. 1 No. 2

Desember 2017

Untuk Kepadatan Relatif (KR) tertinggi terdapat pada ikan Tilan Mastcembetus unicdar sebesar 13.461 \%. Sedangkan Kepadatan Relatif (KR) yang rendah di temukan terdapat pada ikan Kepuntin (Leiocassic micropogon), $1.20481 \%$.

Sedangkan untuk Frekuensi Kehadiran (FK) tertinggi ditemukan pada ikan Tilan (Microphis brachyurus), Lampam (Puntius schwanepeldi), Lais (Criptopterus limpok (Blkr), Gurami (Osphronemus gouramy), Baung (Mystus nemurus) masing-masing $100 \%$. Sedangkan Frekuensi Kehadiran (FK) terendah ditemukan pada ikan Kepuntin (Bagroides melapterus), betok (Anabas tertudineus B.L), Tambakang (Helostoma temmincki), dan Ikan nila (Oreochormis niloticus) masingmasing 33,33-66,66 \%.

Berdasarkan Kriteria penilaian keanekaragaman jenis ShannonWienner, maka Frekuensi Kehadiran (FK\%) Jenis Ikan di Sungai Batang Bungo Kabupaten Bungo Propinsi Jambi dapat dikatakan dengan kehadiran sedang yaitu $64,20 \%$.

\section{Penutup}

1. Kesimpulan

1. Selama penelitian dilakukan, ikan yang berhasil dikumpulkan berjumlah 156 ekor, terdiri dari 16 jenis yang mewakili 5 Ordo, 9 Famili dan 15 Genus.

2. Hasil analisis indeks keanekaragaman jenis menunjukkan indeks keanekaragaman berkisar antara 0,58 hingga 1,46 Indeks keanekaragaman tertinggi di jumpai di Stasiun I (Dusun Buat), Stasiun III (Kelurahan Sungai Pinang) dan terendah terdapat pada Stasiun II di (Dusun Tebat).

Indeks
ojs.umb-bungo.ac.id/index-php/SEMAHJPSP

keanekaragaman jenis ikan disungai Batang Bungo dari 3 stasiun tersebut termasuk dalam kategori sedang. Kepadatan Populasi (KP) tertinggi dari tiga stasiun yaitu: Tilan (Microphis brachyurus) sebesar 0.0042 (individu) / $\mathrm{m}^{2}$. Kepadatan Relatif (KR) tertinggi terdapat pada ikan Tilan Microphis brachyurus sebesar $13.461 \quad \%$. Frekuensi Kehadiran (FK) tertinggi yaitu Tilan (Microphis brachyurus), Lampam (Puntius schwanepeldi), Lais (Criptopterus limpok (Blkr)), Gurami (Osphronemus gouramy), Baung (Mystus nemurus) masingmasing $100 \%$.

2. Saran

1. Perlu adanya penelitian lebih lanjut, agar menambah jenis alat tangkap, di musim sepanjang tahun dan waktu di perpanjang/ditambah.

2. Perlu adanya sosialisasi untuk melibatkan masyarakat dari lembaga konservasi, lembaga pendidikan dan pemerintah setempat mengenai pentingnya Sungai Batang Bungo Kabupaten Bungo Propinsi Jambi terhadap satwa didalamnya khususnya ikan.

3. Perlunya penggunaan alat tangkap yang sesuai dengan karakteristik Sungai.

4. Perlu adanya pendampingan dari Dosen yang bersangkutan kepada Mahasiswa yang melakukan penelitian, agar data yang di peroleh benar-benar berdasarkan fakta dilapangan.

\section{DAFTAR PUSTAKA}

Bappeda Propinsi Jambi. 2010. Profil Letak Wilayah Propinsi Jambi. Jambi 
SEMAH : Journal Pengelolaan Sumberdaya Perairan

VOL. 1 No. 2

Desember 2017

Bengen, Dietriech G,2000.Sinopsis Ekosistem dan Sumberdaya Alam PesisirPusat Kajian Sumberdaya Pesisir dan Lautan-IPB,Bogor.

Bond, C.E. 1979. Biology of Fishes.W.B. Saunders Campany, Philadelphia.

BPS, 2014.Bungo Dalam Angka. 2014 .BPS Kabupaten Bungo

Brotowidjoyo, M.D. 1993. Zoologi Dasar. Cetakan II. Erlangga Jakarta.

Budiyono, 2011, Analisis Pengaruh Penambangan Emas dan Pasir terhadap Kualitas Air dan Keanekaragaman Jenis Ikan di Sungai Batang Bungo Kabupaten Bungo, Tesis Pasca Sarjana Universitas Bung Hatta.

Dinas Perikanan Kabupaten Bungo, 2012. Perairan Umum di Kabupaten Bungo. Bungo Jambi

Djuhanda, T. 1981. Dunia Ikan. Armico. Bandung

Laily, N, 2006, Identifikasi Jenis-Jenis Ikan Teleostei yang tertangkap Nelayan di wilayah Perairan Pesisir Kota Semarang, Skripsi, Fakultas Matematika Dan Ilmu Pengetahuan Alam Universitas Negeri Semarang.

Lalli, C.M and Parsons. T.R.1993. Biological Oceonography and Introduktion. Pergamon. Press, New York.

Kamal. E, 2007. Bahan dan Alat Penangkapan Ikan. Fakultas Perikan dan Ilmu Kelautan.
ojs.umb-bungo.ac.id/index-php/SEMAHJPSP

ISSN : 2580-0736

Universitas Bung Hatta Padang.104 Halaman.

Kent, N. 1987. Teknology Of Cereal Pergamon Press Oxxford, New York.

Kottelat, M; A. J. Whitten; S. N. Kartikasari \& S. Wirjoatmojo. 1993. Freshwater of Western Indonesia and Sulawesi. London: Periplus Edition.

Krebs C.J. 1972. Ecology, The Experimental Analysis of Distribusi and Abundance. Harper and Rows Publiser.

Koesbiono, 1989. Dasar-Dasar Ekologi Umum. IPB. Bogor

Magurran, A.E. 1988. Ecological Diversity and It's measurement, New Jersy: Prcenton University Press

Marshall, N.B. 1982. Biology Of Fishes, New York Capaprinon and Hall.

Mayr. E. 1971. PrinciplebOf Systematik Zoologi. Tata Mc. Graw Hill Publishing Company Ltd. New Delhi

Mochamad Indrawan, 2007: 16-18. Tingkatan Keanekaragamn Hayati.

Moyle, P. B, \& J.J Cech 1989. Fishes, An Inroduktion to Ichthyology. Second Edition. New Jersy : Prentice Hall.

Odum, E P. 1996 .Dasar-Dasar Ekologi : edisi ketiga. Yogyakarta :Gadja Mada University Prees.

Rifa'i. S.A.N., Sukarya \& Z. Nasution, 1983. Biologi Perikanan. Edisi I. 
SEMAH : Journal Pengelolaan Sumberdaya Perairan

VOL. 1 No. 2

Desember 2017

Departemen Pendidikan dan Kebudayaan. Jakarta.

Romimohtarto, K \& S. Juwana. 2001. Biologi Laut. Jakarta: Djambatan.

Rososoedarmo, Soejdran. 1990. Pengantar Ekologi. PT. Remaja Rosdakarya. Jakarta.

Ross. R.. 1997. Fisheries Conservation And Management. Prentice. Hall. Inc. New York.

Saanin. H. 1984. Taksonomi Dan Kunci Identifikasi Ikan Jilid I Dan II. Bina Cipta. Bogor.

Saputra, FM, 2004. Daerah Aliran Sungai Batang Hari, Makalah-pdf Web:

Siagian, C, 2009, Keanekaragaman dan Kelimpahan Ikan serta Keterkaitannya dengan Kualitas Perairan di Danau Toba Balige Sumatera Utara, Tesis, Sekolah Pascasarjana Universitas Sumatera Utara Medan,

Soemadji. 1995. Zoologi. Jakarta: Depdikbud. Kent, G. C. 1987. Comparative Anatomy of The Vertebrates. St. Louis-TorontoSanta Clara: Time Mirror/ Mosby College Publishing.

Sudrajat, A, Darti Satiyani, Sudarto, Ketut Sugama dan Murniyati, 2009,Inventarisasi Keragaman Ikan lokal Air Tawar Propinsi Jambi, Dinas Kelautan dan Perikanan Propinsi Jambi, Jambi, Cetakan ke 2, 81 pp.

Sudrajat, A, Darti Satiyani, Sudarto, Ketut Sugama dan Murniyati, 2009, Inventarisasi
ojs.umb-bungo.ac.id/index-php/SEMAHJPSP

ISSN : 2580-0736

Sukiya. 2003. Biologi Vertebrata. Yogyakarta: Biologi FMIPA UNY.

Sumich, J.L.1992. An Introduktion to The Biology Of Marine Life Fisth Edition WCB WM. C. Brown Publisher. United States Of American, 2460 Kerper Boulevard Dubuqua IA. 52001

Tarp TG, Kailola PJ. 1995. Trawled Fishes Of Southern Indonesia and Northwesternn Australia. Published Australian Development AsistanceBureau (ADAB). Australia.p.293-299

Taufik, 2011. Teknik Identifikasi spesies Ikan.

http://www.bpppbanyuwangi.com. Diakses tanggal 02 Mei 2017

Universitas Muara Bungo, 2011. Panduan Teknis Penulisan Skripsi.

Wahyuningsih dan Barus. 2006. Buku Ajar Iktiologi. Departemen Biologi Fakultas Matematika dan Ilmu Pengetahuan Alam Universitas Sumatera Utara.Medan.

Wooton, J, 1991, Ecology of Teleost Fishes. New York: Chapman \& Hall.

Yustina, 2001, Keaneka Ragaman Jenis Ikan Disepanjang Sungai Rangau , Riau, Sumatera, Journal Nature Indonesia 4(1):1-14(2001) ISSN 1410-9379. di akses tanggal 24 Agustus 2013.

Zottoli, R \& B.H. McConnaughey. 1983. Pengantar Biologi Laut. London: C.V. Mosby Company. 